\title{
From Imagination to Compassion and Democracy: Martha Nussbaum on the Role of Art
}

\section{Ferdinand Indrajaya}

Visual Communication Design Department, School of Design, Pelita Harapan

University, Tangerang, Indonesia, 15811.

PhD Student of STF Driyarkara, Jakarta, Indonesia, 10520.

E-mail: ferdinand.indrajaya@uph.edu

\begin{abstract}
It is undeniable that most of our modern universities are portraying themselves as factory-like institutions which manufacture useful knowledge. The term "useful knowledge" refers to a type of knowledge which directly has immediate payoff and practically commodifiable. Most modern universities are no longer spotlighted as the generator of new knowledge, the influential bodies in civic life and nation-state, the greatest critics of public policies, but reduced to and figuring as a major agent of economic growth. Posting economic growth as the model for universities is a form of corporatism in higher education level. Art disciplines, as a part of humanities, are inevitably framed by such a model. In which, art is understood as a mere aesthetic commodity and the artist is seen as a mechanical subject to be manipulated by profit motifs. This view has been well prevailing, but it is not incontestable. This paper is written as an attempt to critically respond towards such prevailing corporatist view. To do that, the author borrows some philosophical perspectives from an American philosopher, Martha C. Nussbaum (1947-now). Her philosophical accounts on art, imagination, and compassion as a form of distinctive moral emotion are considerably an adversary to the current perspective of art education which has been colonized by corporatism. From her perspective, more than just a mere commodity, art has a significant role in upholding democracy. Art has the power to nurture compassion, in which respect and concern for others are inherent. Respect and concern are the vital-ethical ingredients for democracy. One particular art form which, according to Nussbaum, can nurture compassion, intensively, is a tragedy. Through which, we shall see other people as human beings, not as objects of manipulation. Such philosophical views of hers may re-attune our current perspective on art education.
\end{abstract}

Keywords: art, imagination, compassion, corporatism, democracy

\section{ABSTRAK}

Sulit dipungkiri bahwa kebanyakan dari universitas modern/masa kini kerap menampilkan wajahnya sebagai institusi yang serupa dengan pabrik manufaktur pengetahuan yang berguna. Istilah "pengetahuan yang berguna" merujuk kepada pengetahuan yang berdampak langsung dan secara praktis dapat dikomodifikasi. Kebanyakan dari universitas masa kini tidak lagi disorot sebagai sebuah generator bagi kebaruan pengetahuan, lembaga yang berpengaruh bagi kehidupan civic dan negara bangsa, kritikus terbesar bagi kebijakan-kebijakan publik, akan tetapi terreduksi sebagai agen utama dari pertumbuhan ekonomi. Penempatan pertumbuhan ekonomi sebagai model yang diacu oleh universitas 
sesungguhnya adalah sebuah wujud korporatisme pada aras perguruan tinggi. Disiplin keilimuan seni, sebagai sebuah bagian dari humaniora, turut terbingkai oleh model tersebut. Dari perspektif korporatisme, seni dipahami sekadar komoditas estetis dan sang seniman dipandang sebagai subjek mekanistik yang dapat dimanipulasi oleh motif-motif profit. Pandangan ini masih bertahan dan populer sampai saat ini, akan tetapi tidak berarti tidak dapat dikontestasikan. Makalah ini ditulis sebagai sebuah upaya untuk menanggapi secara kritis pandangan korporatistik tersebut. Dalam rangka mencapai tujuan tersebut, penulis merujuk kepada beberapa pandangan filosofis dari salah satu filosof asal Amerika, yakni Martha Nussbaum (1947-sekarang). Pandangan filosofisnya tentang seni, imajinasi, dan bela rasa sebagai sebuah bentuk emosi moral distingtif adalah lawan dari perspektif tentang pendidikan seni yang telah dikolonisasi oleh korporatisme. Seni, melalui perspektifnya, memiliki peran yang signifikan dalam menegakkan demokrasi; keberadaannya lebih dari sekadar komoditas. Baginya seni berdaya untuk memelihara bela rasa, yang di dalamnya rasa hormat dan kepedulian terhadap yang lain inheren. Rasa hormat dan kepedulian, dalam hal ini, adalah unsur etis yang vital bagi demokrasi. Salah satu bentuk partikular dari seni yang menurut Nussbaum mampu secara intensif memelihara bela rasa, adalah tragedi. Melalui tragedi, kita akan memandang orang lain sebagai manusia, bukan sebagai objek untuk dimanipulasi. Pandangan-pandangan filosofis darinya merupakan ajakan bagi kita untuk menala kembali perspektif yang bertahan hingga kini tentang pendidikan seni.

Kata Kunci: seni, imajinasi, bela rasa, korporatisme, demokrasi

\section{INTRODUCTION}

What is this paper about to share is basically a philosophical reflection regarding the current situation in most higher education institutions and the role of art within such context. The term 'philosophical reflection' generally refers to an attempt to borrow and contextualize Martha Nussbaum's philosophical accounts regarding art within the higher education's current situation. Martha Nussbaum (1947 - ) herself is an American philosopher who is well-versed in Roman and ancient Greek philosophy (www.famousphilosophers.org). Issues such as feminism, politics, ethics, emotion, and also art are mainly wrestled and colouring her philosophical concerns. Specifically, this paper shall try to focus on her philosophical accounts on art (especially tragedy as a form of art), imagination, compassion, and how are these considerably crucial for education in its contribution to preserve democracy.

A question one might ask is: why Nussbaum? In order to answer such question, there are at least three considerations shall be put forward. One may find these three considerations in the Forward of Nussbaum's book entitled Not for Profit: Why Democracy Needs the Humanities, written by Ruth O'Brien. The first consideration relates to Nussbaum's deep and broad knowledge of philosophy and educational theory which cover the Western's and Non-Western's (Nussbaum, 
2010, p. x). This implies that her views are responsibly authoritative. Secondly, it relates to her critical perspective towards a considerably current view on education, in which education is conceived primarily a mere tool for economic growth. According to her, "economic growth does not invariably generate better quality of life," on the contrary, it may lead "the quality of all our lives, and the health of our democracies, at risk" (Nussbaum, 2010, p. xi). This second consideration touches upon the crux of the problem which also is mainly concerned by this paper. The third one is related to her philosophical accounts on art and how it is closely linked with democracy. Through art, we "learn to imagine the situations of others, a capacity that is essential for a successful democracy" (Nussbaum, 2010, p. ix). This implies the importance of imagination in developing compassion which is highly crucial for democracy and art helps us in actualizing it. Such view may help us to re-attune our current perspectives on art: a mere aesthetic object or simply no other than an economic commodity.

In order to deliver what have been put forward, systematically, this paper will start by laying out an existing problematic issue regarding contemporary higher education which is considered to be crucial, namely corporatism. Corporatism within the context of higher education shall be briefly elaborated as a background or an opening for further discussion. There are two considerations which support such decision. First, it tries to describe the current situation in the nowadays higher education institutions. Secondly, it also reflects Nussbaum's critical concern regarding the prevailing perspective on education as a mere tool for economic growth. As the first part of the paper, it shall briefly put forward at least three things. First, it shall put forward the definition of corporatism. This shall be continued by pointing out the penetration of such -ism into the body of current higher education institutions. The last part shall highlight the problematic ethical-philosophical consequences of corporatism within the higher education institutions, which are the impoverished humanity and comatose democracy.

The discussion shall be continued by elaborating in a concise manner, Nussbaum's view on art and its significant role in preserving democracy. Within which, we shall touches upon Nussbaum's accounts of imagination, compassion, and the relation between the two. Through art, imagination shall be triggered and, according to Nussbaum, may potentially lead to compassion, which is necessary for democracy. One form of art which she considers has the powerful capacity in triggering imagination that leads to compassion is tragedy. From her perspective, tragedy is positioned as a paradigmatic form of art which shall make 'compassionate imagination' possible; and it is highly crucial for democracy. It should also be noted that her philosophical account regarding compassion is inseparable from her view on imagination as one of the basic capabilities (or opportunities), which is presupposed inherent within every human being. In short, 
her philosophical conception of compassion is necessarily interrelated with her account of imagination.

\section{CORPORATISM IN HIGHER EDUCATION-A BACKGROUND}

What was once a business enterprise, a factory, an industry, or a merchant, are now racing to assemble university. The impetus to blur the boundaries between the interests of large corporation and industry with that of higher education institution has been well nurtured up until now. The invasion of business corporations into the university are welcomed even though they eventually alter the existence of the institution through the benefits they offer. Instead of suspending our judgment about it, most of us tend to confirm its existence for granted. Nowadays, it is quite often that most of us even view corporatized universities as highly credible and bona fide. This is no longer an assumption or an aspiration, but an explicit recognition which requires to be critically responded.

What has been going on is a vulgar display of corporatism in higher education. Corporatism itself may be defined as an ideological perspective which prioritizes the interest and power of business corporations over society (SuarezVilla, 2009, p. 1). Its unimpeded penetration into the body of higher education institution is reinforced and buttressed by another worldwide accepted ideology, namely Neoliberalism (Waite, 2010, p. 82). Neoliberalism itself is a "theory of political economic practices that proposes that human well-being can best be advanced by liberating individual entrepreneurial freedoms and skills within an institutional framework characterized by strong private property rights, free markets, and free trade. It aims to sustain the sense of competition regarding market forces, strengthen market friendly institutions, and advance individual freedom (Jessop, 2012, p. 1513). What about the role of the state in regards to such aim? The role of the state is to create and preserve an institutional framework appropriate to such practices" (Harvey, 2005, p. 2). Education, under the heading of Neoliberalism, is framed as a resource for global competition and wealth accumulation and the role of the state is confined in promoting such view (Waite, 2010 , p. 84). Under such heading, educational institutions are directed to learning processes which will serve such interests (Sleeter, 2008, p. 145).

How does corporatism practically affect our current and prevailing views regarding the existence of contemporary higher education and its notably primary aspects such as knowledge, the position of university, and the students themselves? First, knowledge is understood as a mere commodity. This shall be exemplified by the wedding of Microsoft and Cambridge University, as reported by The Economist. In the October 1997, The Economist issued its special report entitled "Inside the Knowledge Factory". Generally, the report put forward the 
ongoing global crisis within the realm of higher education institutions worldwide (https://www.economist.com/special-report/1997/10/02/inside-the-knowledgefactory). Such crisis referred to the dedication shifting universities. It was stated that universities were no longer dedicating themselves to pursue knowledge for the sake of knowledge itself. The dedication has been perverted to the pursuit of economic growth and profit through the act of fabricating useful knowledge, supported by the penetration of large business corporation into the body of university. The term 'useful knowledge' refers to knowledge which gives an immediate pay off in a utilitarian sense, such as electrical engineering, computer technology, biotechnology, and the like. They are considered as highly important and crucial for a nation to compete globally and accumulate wealth. How much profit which we can get out of their research and invented-utilizable products, determines the future health of a nation (Nussbaum, 2010, p. 7).

The alliance of Microsoft and Cambridge University was referred by the report as a concrete example. It was stated that how Cambridge was brimming with pride when Microsoft decided to fund the university and choose its site to establish a computer science laboratory (now is known as Cambridge Computer Science and Technology Department). The department's coverage encompasses some considerably useful knowledge, such as computer science, technology, and mathematics as the prominent fields of study. One of the intentions behind the funding, which might be the most salient, is inseparable from Microsoft business' interest to compete with its rivalry, the Silicon Valley in the United States (https://www.independent.co.uk/news/bill-gates-chips-in-to-help-cambridge-

1241153.html). Microsoft needs a knowledge factory of its own to produce the most updated yet patentable innovations in computer technology to compete with its rival globally. Knowledge, innovation, including creativity, in this case, is reduced to a mere commodity which benefits financially.

Secondly, nowadays, the current university is conceived as none the other: a sorting machine. In the year of 2002, Cambridge Ring, was founded. It is an association which its existence is infrastructural to the Computer Science and Technology department. Such association provides updated information, contacts, and business programs exclusively for the department's graduates. The Ring channels Computer Science and Technology's graduates with the computer technology industries (https://www.cst.cam.ac.uk./ring). The association implicitly positions itself as a sorting machine and explicitly also a service provider. From the perspective of the association and also the university itself, students, especially the graduates, are treated like none other than customer. The student-as-customer model is also applied pervasively in most modern or current universities and probably be the most welcomed model within our contemporary 
society. We are here touching upon the third prevailing views regarding corporatism in higher education.

In 1994, the student-as-customer model has been embraced and adopted by a group of UK-based universities. The model itself is no less than a way of business enterprise, an industry, or even a salesman in doing their economictransactional activity. When implemented in an institution of higher education, such model manipulates the students to act accordingly with the logic of marketing (Furedi, 2011, p. 3). The logic which is inherent in marketing activity penetrates so deep thus the distinction between an academic relationship and an economic-transactional one is blurred. Through such model, the university is reduced to a service provider, a pander with academic clothing, which provides what the student-customers want (as if they even really know what they want) rather than educating them to become educated.

From what has been put forward, we can once again highlight how the dedication of higher education has truly shifted once it is infected by corporatism. As previously mentioned, the pursuit of economic growth and profit has been a dominant disposition of most (corporatized) contemporary universities. Such condition is not only made possible and prevailing by the penetration of large business corporation's interests into the body of universities, but also actively buttressed by the significant role of the state. The support from the state flows due to the lucrative outcomes which are gained from the business corporations' infiltration into the universities. It manufactures the three ingredients which are concerning the nation's chief source for sustainable growth and prosperity; they are highly trained specialists, expert knowledge, and scientific \& technological advances (Bok, 2003, p. 1).

The support from the state usually presents in a form of regulatory policies. In Indonesia, such policies may be exemplified by the link and match policy, issued by the Indonesian Ministry of National Education in 1995. The link and match policy was proposed as a response to the rising of unemployed university's graduates. It was initially conceptualized to overcome unemployment issue which was happened nationwide. The conceptualization of such policy was departing from one assumption: the rise of unemployment was caused by the impairment of existing education system (https://www.republika.co.id/berita/shortlink/21227). The policy suggested that such issue might be overcome if universities readjusted their curriculum to accommodate the interests of business corporations and industries. Once the curriculum was able to accommodate the needs of business corporations and industries, the university's graduates should be well employed. From which, competency based curriculum was constituted. 
Such policy implies the position of business corporations and industries as an academic consultant and this legitimates the significant role of the state and higher education in supporting the establishment of corporatism up until today. It suggests that the task of higher education is delivering competent graduates to serve the interests of business corporations and industries (DIKTI, 2003, p. 8). University has become a human factory which produces "generations of useful machines" (Nussbaum, 2010, p. 2) and this will lead us to a greater crisis in humanity yet a comatose democracy. Instead of cultivating imagination, this according to Nussbaum is what makes us human, corporatized higher education polishes the manipulative dexterity.

Corporatized higher education, through its creativity commodification, replaces respect and concern for others (which according to Nussbaum, they grow out of the ability to imagine), with manipulation. By replacing respect and concern with manipulation, corporatism actively participates in putting democracy in a coma. Since democracy is likely depending upon education for its sustenance (Waite, 2010, p. 99), corporatized higher education has a significant role in comatose democracy. In turn, it will replace democracy with corporatocracy. The term corporatocracy refers to "a political system in which powerful corporate interest groups dominate the policy agenda" (Sachs, 2011, p. 104). It is no longer "by the people and for the people', but it is shifting to 'by the corporation and for the corporation' and our current higher education system is definitely has a prominent role in giving birth to it. Up to this stage, we may ask: how does Nussbaum's view on art might be a relevant contesting perspective to such corporatized one? The answer to this question shall be briefly elaborated in the next part.

\section{ART, IMAGINATION, AND COMPASSION FROM NUSSBAUM'S PERSPECTIVE}

Within the context of corporatized higher education, one direct step, which is usually taken to sustain the sovereignty of corporatism, is to make less room for arts and humanities courses, in favor for more 'useful' subjects (Nussbaum, 2010, p. 23). From the perspective of corporatism, such direct step is necessary and considerably proper. Why? Art, according to Nussbaum, is the great enemy of obtuseness and obtuseness is necessary to carry out programs of economic growth which ignore respect and concern for others as the base for democracy (Nussbaum, 2010, p. 23). The artist, as the aesthetic subject, is no reliable servant of any ideology (Nussbaum, 2010, pp. 23-24), especially of the one which oppresses and stunts imagination. By giving no room for art within the realm of higher education, it simultaneously eliminates the vital component for democracy, which is compassion. Art, as part of the humanities, provides "a capacity for 
genuine concern for others" through igniting "the ability to imagine what the experience of another might be like" (Nussbaum, 2010, p. 97). It teaches people to be capable of "living with others without control," manipulation, and objectification (Nussbaum, 2010, p. 101). Such values are definitely not the concerns of Corporatism because they simply useless for financial profit and economic growth.

From Nussbaum's perspective, art has the capacity to ignite one's imagination in acknowledging his existence as part of global citizenship and in turn, such imagination will give rise to compassion which is crucial for preserving democracy. Imagination, in Nussbaum's philosophical account, is understood as one of the capabilities central to human being which enables us to put the wellbeing of others as an end. Capability itself is one of the prominent philosophical views from Nussbaum. Her philosophical ideas of capability are developed and inspired by another philosopher, namely Amartya Sen (1933 - ). Sen himself views capability as "substantial freedoms" or "a set of (usually interrelated) opportunities to choose and to act" (Nussbaum, 2011, p. 20). It is "what is this person able to do and to be" (Nussbaum, 2011, p. 20). Departing from her conception of capability, imagination is an inherent opportunity in someone which will enable her or him to act and to decide who she or he is.

Imagination, from Nussbaum's perspective, is not just a matter of cognition or understood within the realm of epistemology, but it has an ethical dimension. As mentioned previously, it has to do with a possibility to choose an action and deciding who one is; as such unquestionably is presupposed by a certain conception of the good. Such view on imagination is also influenced by her reading of one great Greek philosopher, Aristotle (384 - 322 BC). One philosophical concept from Aristotle which influences Nussbaum in developing her account on imagination is phantasy or phantasia. Phantasia refers to "the active and selective aspect of perception" and "it works closely in tandem with memory, enabling the creature to focus on absent experienced items in their concreteness, and even to form new combinations, not yet experienced, from items that have entered sense experience" (Nussbaum, 1990, p. 77). The linkage of imagination with ethical concern is represented by the deliberative characteristic of perception itself, which is its selective aspect. One's perception of things does not spring forth in indiscriminate manner but it is "something that answers to one of his or her practical interests or concerns" (Nussbaum, 1990, p. 77). It corresponds with one's view of what should be pursued and what should be avoided; it is inevitably related to one's conception of the good.

Through art, imagination is oriented to the good of others. The well-being of others shall be selected as something that is worth pursuing. Through which, the imagination that is cultivated by art is potentially growing a sense of 
compassion towards others. Art, according to Nussbaum, is closely associated with "the ability to think critically; the ability to transcend local loyalties and to approach world problems as a "citizens of the world"; and, finally, the ability to imagine sympathetically the predicament of another person" (Nussbaum, 2010, p. 7). The ability to "to imagine sympathetically the predicament of another person" specifically shows the linkage between imagination and compassion; and this is made possible by acknowledging one's existence as the citizens of the world (not just as an apparatus of the corporate or a bolt of an industrial machine).

The interrelation between imagination and compassion is signified by Nussbaum in a more straightforward manner through her definition of compassion. Compassion, according to Nussbaum, is a form of emotion, namely "an emotion that has been relied on to hook our imaginations to the good of others and to make them the object of our intense care" (Nussbaum, 2001, p. 13). The well-being, the good of others (not economic wealth and profit), is placed as an end for our ethical conduct and this requires active role of imagination which is cultivated by the arts; this is why art is important for democracy. Besides it is closely linked with imagination, Nussbaum's view on compassion is also inseparable from her philosophical account of emotion which is also quite central in her philosophy. In fact, her definition of compassion tries to show how emotion is a point where imagination and concerns for the others' meet.

Nussbaum's view on emotion is different from what is commonly accepted up until today, which is conceived within the feeling and thinking dichotomy (Das, 2017, p. 2). According to her, emotion is not a mere "unthinking forces that have no connection with our thoughts, evaluations, or plans" (Nussbaum, 2001, pp. 26-27). She views emotion as cognitive-evaluative judgment and such view stands as a critical response towards a dominating conception of emotion which still prevails today. It is an adversary to a traditional or commonly Western accepted view on emotions as "objectless feelings of pain and/or pleasure" (Nussbaum, 2001, p. 35). Nussbaum dissents this Western traditional view on emotions. She argues that emotions are not objectless or simply a thoughtless forces. In order to show this, Nussbaum describes her argument in three ways.

First, emotions are not objectless, "they are about something: they have an object" (Nussbaum, 2001, p. 27). Our fear or grief is fear or grief about something. When we experienced fear, our heart trembled or leaped. Fear is always a fear of something and if this something is taken away, then it might just be trembling or heart-leaping. Secondly, the object towards which our emotions are directed is "an intentional object" (Nussbaum, 2001, p. 27). The about-ness of the object is not external but internal. It is not something that being pointed and then let it go. As Nussbaum suggests, it is internal. The about-ness is understood 
internally in a sense that it "comes from my active ways of seeing and interpreting: it is not like being given a snapshot of the object, but requires looking at the object, so to speak, through one's own window (Nussbaum, 2001, p. 28). In grief, we see something or a person as lost, while in love we perceive someone as full of radiance. There is a sense of captivating in the about-ness. The about-ness of something is 'haunting' or enthralling us in such ways thus our gaze is 'locked' and directed towards the object. Thirdly, these emotions "embody not simply ways of seeing an object, but beliefs - often very complex - about the object" (Nussbaum, 2001, p. 28). Our emotions involve certain beliefs about the object and these beliefs are not trivial but invested with highly significant value. For example, in order to be angry, we must believe that something obnoxious has significantly happened to us or someone that happens to be dearly for us. Subsequently, we also believe that this obnoxious situation may have been done by someone willingly or accidentally.

Emotions are, as has been described briefly, not construed and conceived as objectless or unthinking movements. They are not some irrational distractions, but are intelligent responses to the perception of value. As Nussbaum clearly explicates, "they are concerned with value, they see their object as invested with value or importance" (Nussbaum, 2001, p. 30). They proceed from judgments we make concerning the others (objects and people) that are beyond our control but valuable to us. Emotions are "forms of evaluative judgment that ascribe to certain things and person outside a person's own control great importance for the person's own flourishing. Emotions are thus, in effect, acknowledgements of neediness and lack of self-sufficiency" (Nussbaum, 2001, p. 22). The phrase "great importance for the person's own flourishing" involves a wider sense of eudaimonia as a characteristic of emotions, not the narrow or utilitarian sense which leads it to a mere happiness. In a wider sense, it refers to "mutual relations of civic or personal love and friendship, in which the object is loved and benefited for his or her own sake" (Nussbaum, 2001, p. 32). Such eudaimonistic character of emotions is also one of the reasons why Nussbaum strongly suggests that the theory of emotion must be included in the discussion of ethics.

As a form of emotion, compassion is a distinctive moral one. Nussbaum's philosophical account of emotion, again, is greatly influenced by Aristotle. From Aristotle's perspective, compassion (eleos in Greek term), is not conceived as part of evaluative judgment (Deigh, 2004, p. 467). He construes compassion as a painful experience which is dealt by someone caused by the tragic predicament of others. This suffering or tragic predicament befalls to others not on her or his behalf (i.e. disaster-like or catastrophe-like). Someone suffers because of the undeserved suffering happens to others and such suffering might actually befall into him or her beyond his or her control. The term eleos itself is parallel to 'pity' 
in English. In our daily lives, according to Nussbaum, we often use pity, empathy, and sympathy, interchangeably with compassion (Nussbaum, 2001, p. 301). Nevertheless, the difference of those terms is also applied. For example, we can have self-pity, but not self-compassion.

Though we interchangeably use the term pity and compassion quite often, Nussbaum normatively avoids this because of its (pity) pejorative character. Pity, according to her, is fully contained with "nuances of condescension and superiority to the sufferer" (Nussbaum, 2001, p. 301). Empathy, on the other hand, is also different from compassion. It is simply "an imaginative reconstruction of another person's experience, whether that experience is happy or sad, pleasant or painful, or neutral, and whether the imaginer thinks the other person's situation good, bad, or indifferent" (Nussbaum, 2001, p. 302), therefore it is way different from compassion and not even sufficient for it. Sympathy, from Nussbaum's perspective, considerably has the closest meaning to compassion. Its similarity is found on the judgment that "the other person's distress is bad" (Nussbaum, 2001, p. 302). The difference between sympathy and compassion lies in its intensity. According to Nussbaum, compassion is more "intense and suggests a greater degree of suffering, both on the part of the afflicted person and on the part of the person having the emotion" (Nussbaum, 2001, p. 302).

According to Nussbaum, one particular art form which is quite powerful in nurturing compassion, in hooking our imagination to the well-being of others and placing them as the object of our concern intensively, is tragedy. Tragedy is a form of art, a type of drama which presents a subject matter or theme regarding a serious human suffering. It is rooted in our life as human being (Torghabeh, 2018, p. 234). The principle character who suffers usually experiences and deals with his or her tragic predicament which is not the consequences of his or her own past conduct, but due to a misfortune; and misfortune is one of the events in life. The quality of the misfortune is not trivial, but a catastrophic one. One of the tragedies which is used by Nussbaum as an example in her discussion of compassion, is the story of Sophocles' Philoctetes, a Greek tragedy.

The tragic life of Philoctetes was once retold by Nussbaum in "Boston Review", a political and literary online forum. In that forum, she shared the story shortly: "Philoctetes was a good man and a good soldier. On his way to Troy to fight with the Greeks in the Trojan War, he had a terrible accident. He stepped by mistake into a sacred shrine, and his foot was bitten by the serpent who guarded the shrine. It began to ooze with a foul-smelling pus, and his cries of agony disrupted the religious observances of the troops. The commanders therefore abandoned him on a deserted island, with no resources but his bow and arrows. Ten years later, having learned that they cannot win the war without him, they return, determined to trick him into rejoining them. Sick, lonely, hungry, 
exhausted from hunting his own food, Philoctetes still longs for friendship and activity. He greets his visitors with joy, delighted that he can interact with others after his long solitude. And he asks them to have compassion for him, seeing the troubles that life has brought him, troubles from which no human is safe" (Nussbaum, 1998). The story is about a tragic predicament which was experienced and dealt by Philoctetes, the principle character. In that story we can see that the character undergoes a "terrible suffering through no fault of his own" (Nussbaum, 2001, p. 351) or it happens due to a misfortune.

We can easily see that such works of art are not only promoting compassion in their audience "by inviting both empathy and the judgment of similar possibilities," but also "assist our evolving judgments of size" (Nussbaum, 2001, p. 351). This implies, first, that such works of art, like tragedy, encourage us to have compassion towards other's terrible suffering since we ourselves might experience similar predicament. Secondly, what Nussbaum tries to put forward is that tragedy may assist our evolving judgment regarding "size". The magnitude of Philoctetes's suffering, although it is a fiction, is incomparable to, for example, someone who can't go to his or her office because of the flood. The size of Philoctetes suffering may awake our awareness about him as fragile and vulnerable human being, as we are. We can no longer see him as a military object, an instrument, or within the context of Corporatism, a means to serve the interests of business and industry. The story strips down all the attributes which was previously adhered to the principle character and leaves him as simply human being. Not an object to be manipulated, but a human being who deserves respect. This kind of respect and concern is what constitutes and underlies democracy; this is why democracy needs tragedy.

\section{CLOSING REMARKS - A CONCLUSION}

This paper is not written as an attempt to against totally the involvement of business' or corporation's interest within the context of current higher education institution. Nor to reject the importance of scientific subjects as useful knowledge. It is an invitation to critically reflect upon the emerging ethical consequences from taking business' or corporation's interests as synonymous to the interests of education. When we embrace corporatism as the only proper ideology for us to fully grasp the existence of higher education, we put humanity prone to crisis. Reducing higher education as a mere tool for economic growth and profit equals to the impoverishment of humanity. It also paralyzes the capacity of art in igniting imagination and fostering compassion which are highly crucial for a healthy democratic living. At this point, Nussbaum's views on art (tragedy in particular), 
imagination, and compassion give us a considerably valuable insight to reflect on such matter.

Tragedy ignites, activates, and directs our imagination towards the good of other. Subsequently, it fosters compassion as well as our sense of humanity. It drives and captivates us to contemplate the fragility and finitude of our being as human. It is powerful to encourage "pleasure of the most difficult type: the pleasure of contemplating our mortality and our vulnerability to the worst disasters in life" (Nussbaum, 2001, p. 352). Furthermore, art in general does not only teach us to embrace our own vulnerable lives pleasantly, but as we see through tragedy, it also encourages us to embrace the lives of others. It teaches us about the same and different, the known and the new, and simultaneously who am I and what is beyond myself (Enslin, 2013, p. 66). Within which, is implied what has been inherent in the meaning of education itself that is vital for democracy: the civilization of human being as human being (Yoldaş, 2015, p. 545, Anttila, 2018 , p. 62). Art educates in a sense that it lies down the very necessary condition for not only democracy, but humanity.

\section{REFERENCES}

Anttila, Eeva. 2018. "Art Education Promotes the Development of The Child and Society." In Improving the Quality of Childhood in Europe, edited by Michiel Matthes, Lea Pulkkinen, Christopher Clouder, Belinda Heys, 6172. Brussels: Alliance for Childhood European Network Foundation.

Bok, Derek. 2003. Universities in the Marketplace: The Commercialization of Higher Education. New Jersey: Princeton University Press.

Das, Krishanu K. "A Theoretical Approach to Define and Analyze Emotions." In International Journal of Emergency Mental Health and Human Resilience, 19(4), 1-14.

Deigh, J. 2004. "Nussbaum's Account of Compassion." In Philosophy and Phenomenological Research, 68(2), 465-472.

DIKTI. 2003. Pendidikan Tinggi Indonesia dalam Lintasan Waktu dan Peristiwa. Jakarta: Universitas Indonesia.

Enslin, Penny. 2013. "Artistic Education and the Possibilities for Citizenship Education." In Citizenship, Social, and Economic Education, 12(2), 62-70.

Furedi, Frank. 2011. "Introduction to the Marketisation of Higher Education and the Student as Consumer." In The Marketisation of Higher Education and the Student as Consumer, edited by Mike Molesworth, Richard Scullion, Elizabeth Nixon, 1-7. New York: Routledge. 
Harvey, David. 2005. A Brief History of Neoliberalism. New York: Oxford University Press Inc.

Jessop, Bob. 2012. "Neoliberalism." In The Wiley-Blackwell Encyclopedia of Globalization, First Edition, ed. George Ritzer. New Jersey: Blackwell Publishing, Ltd.

Nussbaum, M.C. 1990. Love's Knowledge: Essays on Philosophy and Literature. New York: Oxford University Press.

Nussbaum, M.C. 2001. The Upheavals of Thought: The Intelligence of Emotions. New York: Cambridge University Press.

Nussbaum, M.C. 2010. Not for Profit: Why Democracy Needs Humanity. Princeton: Princeton University Press.

Nussbaum, M.C. 2011. Creating Capabilities: The Human Development Approach. Massachusetts: The Belknap Press of Harvard University Press.

RISTEKDIKTI. 2017. Rencana Induk Riset Nasional Tahun 2017 - 2045. Jakarta: Kementrian Riset, Teknologi, dan Pendidikan Tinggi.

Sachs, Jeffrey. D. 2011. The Price of Civilization: Reawakening American Virtue and Prosperity. New York: The Random House Publishing Group.

Sleeter, Christine E. "Teaching for Democracy in an Age of Corporatocracy." In Teachers College Record, 110(1), 139-159.

Suarez-Villa, Luis. 2009. Technocapitalism: A Critical Perspective on Technological Innovation and Corporatism. Philadelphia: Temple University Press.

Torghabeh, Rajabali A. 2018. "The Study of Revenge Tragedies and Their Roots." In The International Journal of Applied Linguistics \& English Literature, 7(4), 234-237.

Waite, Duncan and Susan F. Waite. 2010. "Corporatism and its Corruption of Democracy and Education." In Journal of Education and Humanities: Theory and Practice, 1(2), 81-106.

Yoldaş, Özlem K. 2015. "Civic Education and Learning Democracy: Their Importance for Political Participation of Young People." In Procedia Social and Behavioral Sciences, Vol. 174, 544-549.

\section{ONLINE REFERENCES}

About I Department of Computer Science and Technology. Retrieved from https://www.cst.cam.ac.uk/about

Cambridge Ring. Retrieved from https://www.cst.cam.ac.uk./ring 
Inside the Knowledge Factory. (1997, October 2). Retrieved from https://www.economist.com/special-report/1997/10/02/inside-theknowledge-factory

Nussbaum, M.C. (1998, March). Victims and Agents. Retrieved from https://bostonreview.net/archives/BR23.1/nussbaum.html

Wardiman: Dunia Pendidikan Harus Link dan Match. (2008, Desember 19). Retrieved from https://www.republika.co.id/berita/shortlink/21227

Ward, L. (1997, September 26). Bill Gates chips in to help Cambridge. Retrieved from https://www.independent.co.uk/news/bill-gates-chips-in-to-helpcambridge-1241153.html

What is Democracy. (2004, January 21). Retrieved from https://web.stanford.edu/ Idiamond/whaIsDemocracy012004.htm 